\title{
Community Participation on Flood Management in Hulu Sungai Tengah District South Kalimantan Province
}

\author{
Akhmad Nafarin ${ }^{1}$, Sidharta Adyatma ${ }^{2}$, Deasy Arisanty ${ }^{2, *}$ \\ ${ }^{1}$ Biology Education, Faculty of Teaching and Science Education, Lambung Mangkurat University, Indonesia \\ ${ }^{2}$ Geography Education, Faculty of Teaching and Science Education, Lambung Mangkurat University, Indonesia
}

Copyright $\mathrm{O} 2017$ by authors, all rights reserved. Authors agree that this article remains permanently open access under the terms of the Creative Commons Attribution License 4.0 International License

\begin{abstract}
Floods have an impact on people's lives. Efforts to address the effects of flooding need to involve the community. This research examines the public participation in the disaster area in Hulu Sungai Tengah District. This research is designed using a survey approach to the community in flood prone areas in Hulu Sungai Tengah District. Data is obtained through questionnaires with the number of sampling is 380 people. The results show that community participation in flood prevention is high-very high category. People have the participation in form of labor and money. The problems of flood-prone areas in Hulu Sungai Tengah District are lack of public awareness of the signs of impending floods; low information about the dangers of floods; and no early warning system for floods from government.
\end{abstract}

Keywords

Management

Participation, Community-based, Flood

\section{Introduction}

Disaster is an event or series of events that threaten and disrupt the lives and livelihood of the community caused either by natural factors or non-natural and human factors that can cause damage and lead to losses in the form of casualties, property, the psychological impact, and damage development results [1-3]. One type of disasters is floods. Flooding is a hydro-meteorological disaster that occurs in every rainy season.

A total of 5,590 main river and 600 among the main rivers are potentially flooding. Flood prone area that covered by main rivers is reach 1.4 ha. The extent of prone areas to flooding is caused by changes of land use, environmental degradation, and high rainfall [4].

Floods cause damage in the form of damage to wetland, settlements, public infrastructure and casualties. The disadvantage is even greater if the economic and governmental activities are also disrupted. Flooding has caused additional financial burden countries, mainly to rehabilitate and restore the function of damaged infrastructure [4]

Preparedness in facing flood helps community establish and plan the necessary actions during floods [5]. Community participation is aimed at finding a solution to a problem in a community. The solutions assist the communities in determining the action to be performed during floods [6]. Community participation is one of the stakeholders in preventive action and mitigation of floods [7].

Floods in every rainy season are occurred in Hulu Sungai Tengah District, South Kalimantan Province. Flooding has caused various damages including casualties and settlements damage. According to statistics of the disaster management area in 2012, floods have caused death of the victim [8]. Flooding that occurred in February 2016 has flooded in Hantakan Sub District, Hulu Sungai Tengah area with a height of $60 \mathrm{~cm} \mathrm{[9].}$

Community participation in dealing with floods in order to reduce the impact of flooding is indispensable. Communities will determine the appropriate action to tackle the flooding. Therefore, the purpose of this research is to analyze the participation of community for facing the flood in Hulu Sungai Tengah, South Kalimantan.

\section{Materials and Methods}

This research is designed using a survey approach to understand the community participation in flood-prone areas in Hulu Sungai Tengah District, South Kalimantan. Hulu Sungai Tengah District is located in $2^{\circ} 27^{\prime} 5.21^{\prime \prime} \mathrm{S}$ $2^{\circ} 46^{\prime} 54.55^{\prime}$ S, and $115^{\circ} 8^{\prime} 56.96 " \mathrm{E}-115^{\circ} 53^{\prime}$ 32.52" E. Hulu Sungai Tengah has 11 sub districts, and 169 villages. The flood vulnerability Sub-district in Hulu Sungai Tengah is Haruyan, Batu Benawa, Hantakan, Batang Alai Selatan, Batang Alai Timur, and Barabai. The research area is presented in Figure 1.

Respondents in this research are from communities that 
affected by floods. The samples are collected from the vulnerability flood area such as Haruyan, Batu Benawa, Hantakan, Batang Alai Selatan, Batang Alai Timur, and Barabai. The number of respondents in this research is 380 people. Data is obtained through questionnaires. Questionnaire is method to obtain the information from appropriate numbers of people [10].

This study uses quantitative analysis. The stages of data processing in this study are editing, coding, and tabulating. Once the data is processed, then the data are analyzed by using descriptive analysis using percentages and frequency distribution. Percentages equation is presented below:

$$
\begin{gathered}
p=\frac{f}{n} \times 100 \\
p=\text { percentages } \\
f=\text { frequency } \\
n=\text { number of cases }
\end{gathered}
$$

Frequency distribution is used to understand the level of community participation. The classification of community participation is presented in Table 1. The equation of frequency distribution [11] follows:

$$
\begin{gathered}
r=D_{\max }-D_{\min } \\
k=1+3.3 \log (n) \\
I=\frac{r}{k} \\
r=\text { Data Ranges } \\
D_{\text {max }}=\text { maximum value } \\
D_{\text {min }}=\text { minimum value } \\
k=\text { number of classes } \\
n=\text { number of cases } \\
I=\text { interval class length }
\end{gathered}
$$

Table 1. Classification of Community Participation

\begin{tabular}{|c|c|}
\hline Interval & Classes \\
\hline$>35$ & Very High Participation \\
\hline $29-35$ & High Participation \\
\hline $22-28$ & Middle \\
\hline $15-21$ & Low Participation \\
\hline $8-14$ & Very Low Participation \\
\hline
\end{tabular}

Source: Data Analysis (2016)

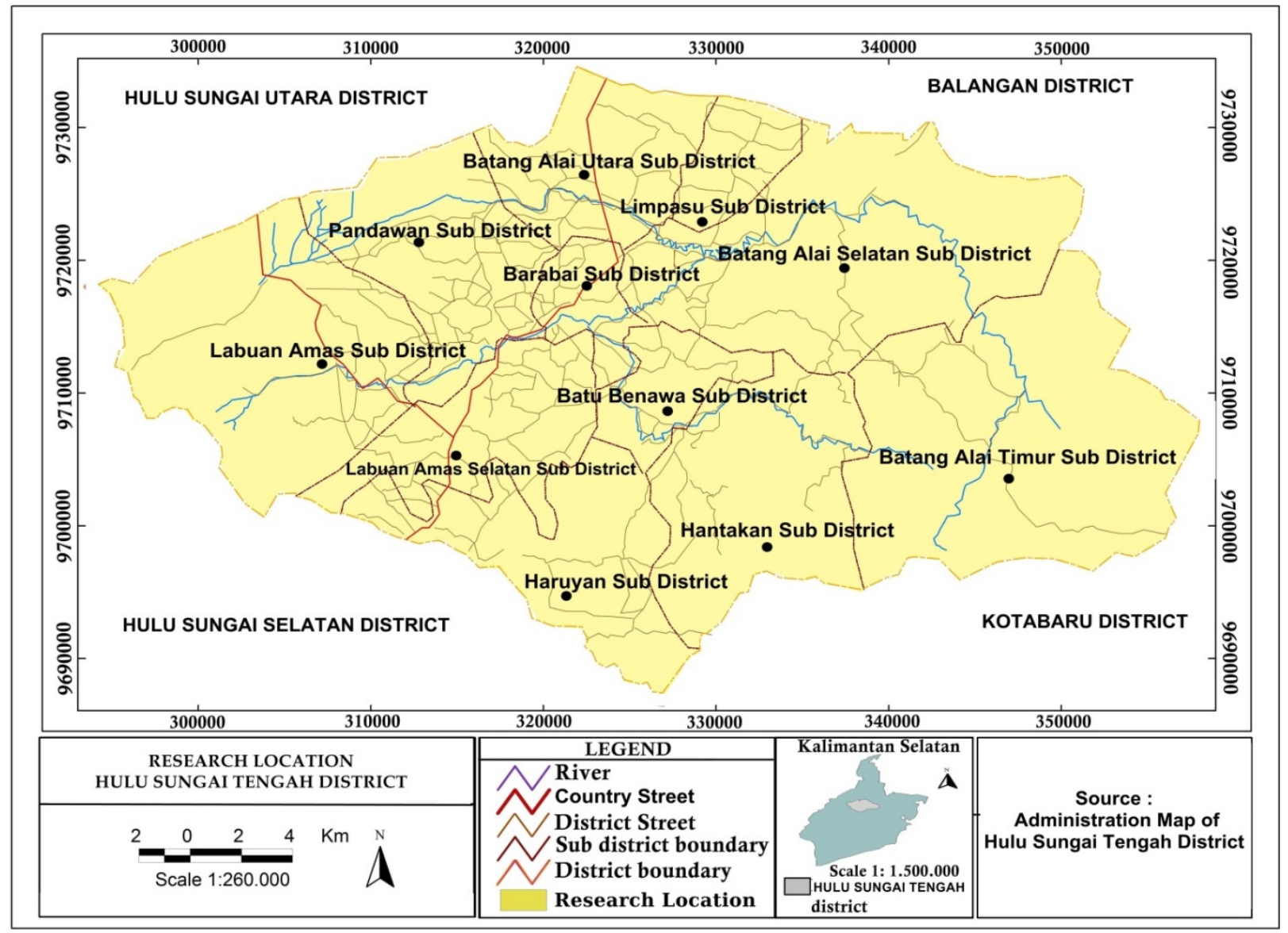

Figure 1. Research location 


\section{Result and Discussion}

\subsection{Characteristics of Respondents}

a. Gender

Grouping the number of respondents based on gender is presented in Table 2.

Table 2. Number of Respondents based on Gender

\begin{tabular}{|c|c|c|c|}
\hline No & Gender & Frequency & Percentage (\%) \\
\hline 1 & Female & 319 & 84 \\
\hline 2 & Male & 61 & 16 \\
\hline \multicolumn{2}{|c|}{ Total } & 380 & 100 \\
\hline
\end{tabular}

Source: Primary Data Analysis, 2016

Table 2 showed that the gender of respondents in research area is female $(84 \%)$ and male $(16 \%)$. This means that most respondents are female, because her husband works for a living.

\section{b. Ages}

Grouping the number of respondents by age of the community in flood-prone areas in Hulu Sungai Tengah district is presented in Table 3 below.

Table 3. Number of Respondents by Age Group

\begin{tabular}{|c|c|c|c|}
\hline No & Age & Frequency & Percentage (\%) \\
\hline 1 & $<35$ & 143 & 38 \\
\hline 2 & $35-50$ & 199 & 53 \\
\hline 3 & $>50$ & 38 & 10 \\
\hline \multicolumn{2}{|c|}{ Total } & 380 & 100 \\
\hline
\end{tabular}

Source: Primary Data Analysis, 2016

Table 3 shows that a total of 143 respondents or $38 \%$ with age $<35,199$ respondents or $53 \%$ with ages $35-50$, and 38 respondents or $10 \%$ with age $>50$. Most respondents in this study are aged $35-50$ years. Hence, people who stay in flood prone area are dominated by ages $35-50$ years.

\section{c. Type of Work}

Grouping the number of respondents by type of work community in flood prone areas in Hulu Sungai Tengah district is presented in Table 4 below.

Table 4. Number of Respondents by Type of Work

\begin{tabular}{|c|c|c|c|}
\hline No & Type of work & Frequency & $\begin{array}{c}\text { Percentage } \\
(\mathbf{\%})\end{array}$ \\
\hline 1 & Farmer & 142 & 37.37 \\
\hline 2 & Civil & 36 & 9.47 \\
\hline 3 & Entrepreneur & 81 & 21.32 \\
\hline 4 & Retired & 22 & 5.79 \\
\hline 5 & Trader & 64 & 16.84 \\
\hline 6 & Construction workers & 10 & 2.63 \\
\hline 7 & Industrial Workers & 25 & 6.58 \\
\hline 8 & Other & 0 & 0 \\
\hline & Total & 380 & 100 \\
\hline
\end{tabular}

Source: Primary Data Analysis, 2016
Table 4 shows that as many as 142 respondents $(37.37 \%)$ are a farmers, 81 respondents $(21.32 \%)$ are self-employed, 64 respondents $(16.84 \%)$ are traders, 36 respondents or $(9.47 \%)$ are civil servants/police/military, 25 respondents $(6.58 \%)$ are industrial workers, 22 respondents $(5.79 \%)$ are is a retired, 10 respondents $(2.63 \%)$ are construction worker. The type of respondents job located in prone area in Hulu Sungai Tengah District are dominated by farmers, due to the research location is agriculture area.

\subsection{Community Participation in the Implementation of Flood Disaster Program}

\section{a. Role of Communities}

The role of regional communities in flood prone area to the disaster management program in Hulu Sungai Tengah district is presented in Table 5 below.

Table 5. Role of Community in Flood Disaster Management Program

\begin{tabular}{|c|c|c|c|}
\hline No & $\begin{array}{c}\text { Community } \\
\text { Participation }\end{array}$ & Frequency & Percentage (\%) \\
\hline 1 & Has active participation & 149 & 39.22 \\
\hline 2 & $\begin{array}{c}\text { Do not have active } \\
\text { participation }\end{array}$ & 231 & 60.78 \\
\hline & Total & 380 & 100 \\
\hline
\end{tabular}

Source: Primary Data Analysis, 2016

Table 5 shows that 231 respondents $(60.78 \%)$ does not play an active role in any flood disaster management program in their area, 149 respondents (39.22\%) has an active role in any flood disaster management program in their area. The community is only active during flood event, but they do not active for preventing flood disaster.

\section{b. Form of Participation}

Forms of community participation in the implementation of flood disaster management program in flood prone areas Hulu Sungai Tengah District can be seen from the shape of its assistance given in Table 6 below.

Table 6. Form of Public Participation

\begin{tabular}{|c|c|c|c|}
\hline No & $\begin{array}{c}\text { Participation } \\
\text { Form }\end{array}$ & Frequency & Percentage (\%) \\
\hline 1 & Money & 67 & 17.65 \\
\hline 2 & Labor & 313 & 82.35 \\
\hline 3 & Goods & 0 & 0 \\
\hline 4 & Other & 0 & 0 \\
\hline & Total & 380 & 100 \\
\hline
\end{tabular}

Source: Primary Data Analysis, 2016

Table 6 shows that 313 respondents $(82.35 \%)$ give labor as a form of participation or assistance in the implementation of the flood disaster management program in Hulu Sungai Tengah District. About 67 respondents (17.65\%) give money as assistance in the implementation of the flood Disaster 
Management program. That is, the major form of assistance given by society in flood prone area in Hulu Sungai Tengah is labor. It is also reinforced by the frequent of voluntary work undertaken by local community to clean up the environment where they live.

\section{c. Constraints in Communities Participating}

The obstacles that people face in participating in the implementation of the flood disaster management program in Hulu Sungai Tengah district is presented in Table 7 below.

Table 7. Constraints in Communities Participating

\begin{tabular}{|c|c|c|c|}
\hline No & Obstacles & Frequency & Percentage (\%) \\
\hline 1 & $\begin{array}{c}\text { Not yet know the signs of } \\
\text { flood }\end{array}$ & 231 & 60.78 \\
\hline 2 & Busy at work & 186 & 49.00 \\
\hline 3 & $\begin{array}{c}\text { Considers floods as usual } \\
\text { disaster }\end{array}$ & 134 & 35.29 \\
\hline 4 & $\begin{array}{c}\text { Not yet know the } \\
\text { information about the } \\
\text { dangers of flooding }\end{array}$ & 149 & 39.22 \\
\hline 5 & $\begin{array}{c}\text { Not yet know flood } \\
\text { evacuation route }\end{array}$ & 328 & 86.27 \\
\hline
\end{tabular}

Source: Primary Data Analysis, 2016

Table 7 states that 231 respondents $(60.78 \%)$ do not know the signs of impending floods, 186 respondents (49\%) expresses a preference to work than following the flood disaster management programs that exist, 134 respondents $(35.29 \%)$ declared that flood disaster considers usual or unnecessary responded excessively, 149 respondents $(39.22 \%)$ claimed not yet know the information about the flooding, 328 respondents $(86.27 \%)$ claimed not yet know the evacuation route in case of flooding. The most constraints of community in participating in the implementation of the flood disaster management program is not yet know the evacuation route and do not know the signs of impending floods.

The classification of community participation level during flood event is presented in Table 8 .

Table 8. The Community Participation Level

\begin{tabular}{|c|c|c|c|}
\hline Interval & Classes & Frequency & Percentage (\%) \\
\hline$>35$ & $\begin{array}{c}\text { Very High } \\
\text { Participation }\end{array}$ & 13 & 3.42 \\
\hline $29-35$ & High Participation & 367 & 96.57 \\
\hline $22-28$ & Middle & 0 & 0 \\
\hline $15-21$ & Low Participation & 0 & 0 \\
\hline $8-14$ & $\begin{array}{c}\text { Very Low } \\
\text { Participation }\end{array}$ & 0 & 0 \\
\hline
\end{tabular}

Source: Data Analysis (2016)

Community participation in flood prone areas of Hulu Sungai Tengah based on the results of the study is high-very high, as much as $96.57 \%$ of respondents have participation during flood disaster event. The people give the assist in form of labor and money. Community has the important role to decrease the effect of flood for the community.
The government has the important role for preventing the flood disaster. The government is needed to give the educating and training for the community for preventing the flood disaster; hence the people participation is not only in form of labor and money. People can manage the disaster to decrease the effect of disaster.

Wesli [7] say that community participation problem in flood prevention is low of the opportunity provided by the local government to cope with the disaster. Women are less involved in dealing with floods, whereas women are particularly vulnerable during floods [12]. The local government plays an important role in the response to the flood disaster. The integration between communities could increase flood disaster efforts [13].

Community participation in the study area is in the form of money and power. This is according to research from Nisa' [14], the main participation are labor participation and social participation. Forms of community participation are not at the stage of thinking in disaster management.

Training and community involvement in dealing with floods needs to be done to increase community participation. Based on research from Hossain [15], mentioned that the training and upgrading of social workers, university and academic in the management of disasters by making disaster management in their curricula to make young people more prepared to deal with disasters.

\section{Conclusions}

Community participation of flood prone areas in Hulu Sungai Tengah based on the results of the study is high-very high participation. Communities participate in flood disaster provides assistance in labor and money. Labor are the highest form of participation by local communities in flood prone area of Hulu Sungai Tengah. Constraints in research area are no understanding the signs of flooding, busy in they working, an unimportant event, low informed about the dangers of flooding, and no understanding the flood evacuation route.

\section{Acknowledgements}

This research was funded by the Lambung Mangkurat University. Researchers would like to thank for the rector of the Lambung Mangkurat University on research grants. In addition, the authors would like to thank for enumerators helping during field data collection.

\section{REFERENCES}

[1] Bakosurtanal and PSBA. Guide of Natural Disaster Risk Mitigation Preparation in Indonesia. Research Report. 
Yogyakarta: Universitas Gadjah Mada; 2002.

[2] Law of Indonesia No. 24 in Year 2007. Guidelines for Disaster Management; 2007

[3] Regulation of the National Disaster Management Agency of Indonesia No. 4 in year 2008. Guidelines for the Disaster Management Plan; 2008.

[4] Water Resources and Irrigation Directorate of Indonesia. Flood Mitigation Policies in Indonesia. Research Report; 2003.

[5] Umar N. Knowledge and Community Preparedness for Disaster Flood Preventing in Bolapapu, Kulari Sigi District of Central Sulawesi. The Soedirman Journal of Nursing 2013; 8: 3.

[6] Santoso WR. Community Participation for Floods Preventing in Pekanbaru. Jom FISIP 2014; 1: 2.

[7] Wesli. Spatial Assessment and Public Participation as Flood Control Efforts in North Aceh District. Teras Jurnal 2011; 1: 1

[8] Regional Disaster Management Agencies of South Kalimantan Province. Disaster Statistic of South Kalimantan Province in Year 2012. Research Report; 2012.
[9] Media Indonesia. Flood occurs in South Kalimantan; 2016. Available in

URL(http://mediaindonesia.com/news/read $/ 28552 / \mathrm{kalimantan}$ -selatan-mulai-dilanda-banjir/2016-02-13)

[10] Lindsay JM. Techniques in Human Geography. Taylor \& Francis e-Library; 2001.

[11] Riadi E. Statistics Research (Analysis of Manual and IBM SPSS). Yogyakarta: Andi Offset; 2016.

[12] Handayani R. Analysis of Life Quality Women and Vulnerability Flood (Undar Andir Villages, Kragilan Sub-District, Serang District), Jurnal Ilmiah Niagara 2013; 5:3

[13] Shaw R. Critical Issues of Community Based Flood Mitigation: Examples from Bangladesh and Vietnam. Journal of Science \& Culture Special Issue on Flood Disaster Risk Reduction in Asia 2006; 72:1-2

[14] Nisa' F. Disaster Management of flood, tornado, and landslides in Jombang, JKMP 2014; 2:2.

[15] Hossain Md A. Community Participation in Disaster Management: Role of Social Work to Enhance Participation, Antrocom Online Journal of Anthropology 2013; 9:1. 